\title{
Simulation analysis of wastes gasification technologies
}

\author{
Leszek Stępień1 ${ }^{1, *}$, Marek Ściążko ${ }^{2}$, Grzegorz Czerski ${ }^{1}$, and Łukasz Kiełtyka ${ }^{1}$ \\ ${ }^{1}$ AGH w Krakowie, al. Mickiewicza 30, 30-060 Kraków \\ ${ }^{2}$ Instytut Chemicznej Przeróbki Wegla, ul. Zamkowa 1, Zabrze
}

\begin{abstract}
Each year a significant growth in the amount of wastes generated is observed. Due to this fact technologies enabling utilization of wastes are needed. One of the ways to utilizes wastes is thermal conversion. Most widely used technology for thermal conversion is gasification that enables to produce syngas that can be either combusted or directed to further synthesis to produce methanol or liquid fuels. There are several commercially available technologies that enable to gasify wastes. The first part of this study is subjected to general description of waste gasification process. Furthermore the analysis and comparison of commercially available gasification technologies is presented, including their process arrangement, limits and capabilities. Second part of the study is dedicated to the development of thermodynamic model for waste gasification. The model includes three zones of gasification reactors: drying, gasification and eventually ash melting. Modified Gibbs minimization method is used to simulate gasification process. The model is capable of predicting final gas composition as a function of temperature or equivalence ratio. Calculations are performed for a specified average wastes composition and different equivalence ratios of air to discuss its influence on the performance of gasification (temperature of the process and gas composition). Finally the model enables to calculate total energy balance of the process as well as gasification and final gas temperature.
\end{abstract}

\section{Introduction}

Thermochemical conversion of wastes, represented by gasification process, has a relatively short history, but since the beginning of 1990's it became a commercially available technology. Since then, considerable growth in the amount of converted wastes is observed. As a result in 2010 over $5 \mathrm{mln}$ tonnes of wastes were converted thermally worldwide. Main advantages of thermal conversion of wastes are: strong reduction of the waste in mass (about $70-80 \%$ ) and in volume (about 80-90\%), destruction of organic contaminants, such as halogenated hydrocarbons, utilization of recyclables from the thermal residues, such as ferrous and non-ferrous metals from bottom ash and slag, reduction of greenhouse gas emissions from anaerobic decomposition of the organic wastes, land savings due the decreased volume resulting in smaller landfills [1-3].

\footnotetext{
* Corresponding author: 1stepien@agh.edu.pl
} 
Gasification is a process that has been known for ages. At first only coal was used in commercial scale, but with time some other organic feedstock like biomass or different kind of wastes were also tested and used. Its main idea is to convert solid organic substance into useful gas in a presence of a gasifying agent. The producer gas in case of oxygen blown gasification consists mainly of carbon monoxide and hydrogen with the share depending on process conditions and reactor applied. In a case of air gasification, average low calorific value (LHV) of obtained gas is in the range between 4-6 MJ/m3 due to high fraction of nitrogen in a product, while for oxygen gasification it gives between 10-15 MJ/m3. Addition of steam as leads to the increased hydrogen concertation, which is desirable in case of using syngas for chemical synthesis.

Nowadays over $200 \mathrm{mln} \mathrm{Mg}$ of coal is gasified worldwide. Main products of gasification is syngas, used for the production of methanol or hydrogen which is then utilized for ammonia synthesis. Although gasification is very well known and widely used technology its implementation to waste conversion is quite recent. The main obstacle is the heterogeneity of wastes, including various chemical composition, particle sizes and heating value. That is the reason why special pretreatment process are required to operate any waste conversion facility and that needs to include drying, crushing and mixing.

On a map of various conversion technologies gasification of wastes can be placed between pyrolysis and combustion. Main differences concern the temperature and excess of air (oxygen) used in the process (Fig. 1). In a commercial practice each of these technologies is mainly used for specific feedstock, for instance pyrolysis is mainly used for obtaining oils from tires and other synthetic materials but is not necessarily recommended for municipal and commercial wastes. In case of combustion processes the feedstock is not that important as in case of pyrolysis, but amount of flue gas, which has to be cleaned, is very large (approximately $14 \mathrm{~m}^{3} / \mathrm{kg}$ waste) what increases both the equipment size and operational costs. For this reasons gasification presents itself as a most advisable technology for waste conversion.

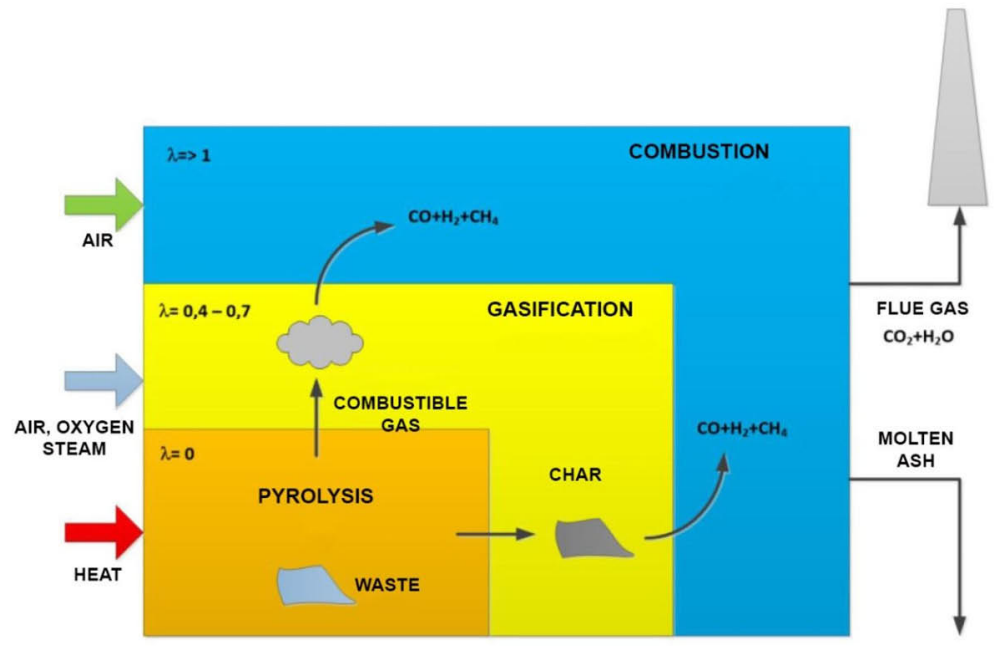

Fig. 1. Different methods of thermal waste conversion

Gasification process can be performed in various types of gasifiers: moving bed, fluidized bed or entrained, but in a case of waste gasification only the first two are applicable. There are many types of moving bed reactors, but the most common are the ones fed from the top, where the feedstock is moving downward in the counter current to gasifying agent. In the top zones the feedstock is dried, then undergoes pyrolysis and finally the char is gasified and 
obtained ash can be melted in the bottom zone of the reactor. Average temperature in the gasification zone can reach approximately $1100-1150 \mathrm{~K}$ and in the bottom part it can reach up to $1700-1900 \mathrm{~K}$. This high temperature also provides the possibility to utilize hazardous, toxic and medical wastes, which is not possible in case of lower temperature reactors. To obtain such high temperature the feedstock need to be improved, which can be done by addition of met coke, that not only increases the calorific value of feedstock but also serves as a kind of grate that enables molten ash to flow downward. In that case it also necessary to use oxygen enriched air to increase the temperature. Finally ash, from this type of reactors can be collected in two ways molten or granulated after cooling and separation process.

Other reactor that can be used for waste conversion is fluid bed gasifier. Its biggest advantage is almost ideal mixing and as a result better mass and energy transfer between gas and solid phase. But on the other hand it is more difficult in operation, because it requires preprocessing of waste such as drying and grinding to specific particle size. Usually one of the particle dimensions shouldn't exceed $6 \mathrm{~mm}$, otherwise there is a risk of choking and defluidization. Fluid bed reactor also requires addition of sand to improve the performance of fluid bed and its stability. The temperature reached in this type of beds does not exceed $1100 \mathrm{~K}$ which is too low in case of processing medical wastes. The solution to that problem is to install upstream the additional equipment for a gas processing, for instance plasma reactor that will be able to increase the temperature up to at least $1500 \mathrm{~K}$ and reduce the amount of dioxins and other impurities in produced gas.

\section{Technology review}

Fig. 2 shows basic types of technological systems used in gasification facilities. They can be divided into four different groups:

a) single step gasification without any additional units,

b) gasification with built-in plasma torch,

c) gasification with the addition of coke

d) gasification with external plasma reactor.
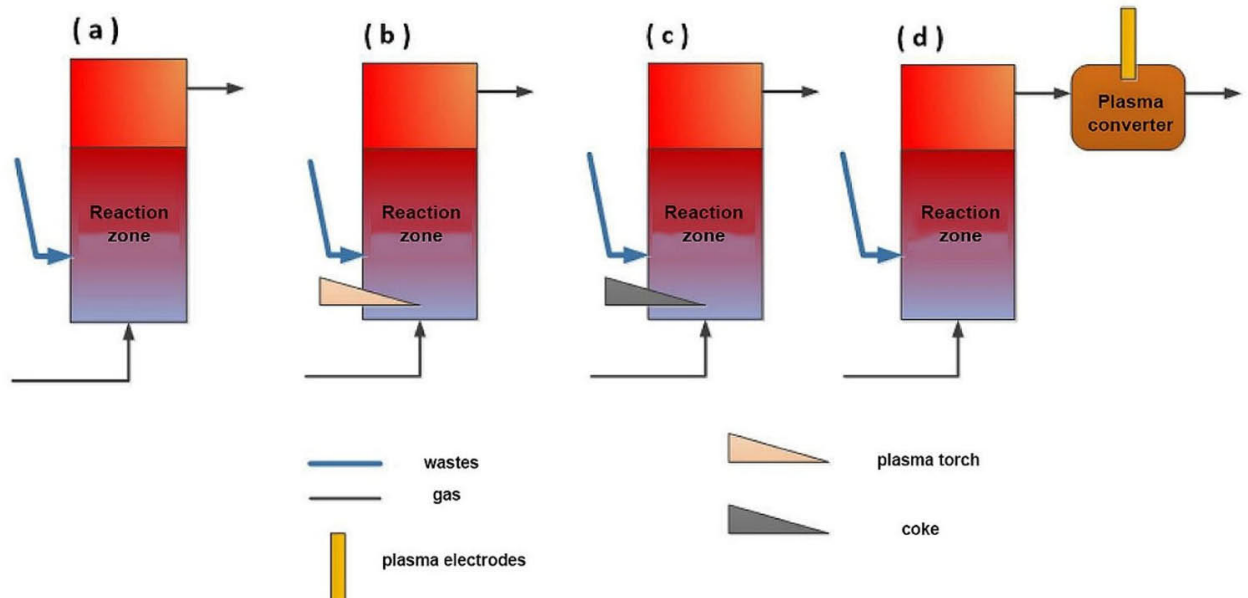

plasma torch

coke

Fig. 2. Basic technological systems for waste gasification

Considering integration of technological units and systems two main groups can be distinguished, that result in a legal qualification of the whole facility what is shown in Fig. 3. First group (A) includes integrated gasification and combustion facilities, that gasify 
wastes and then immediately combust syngas. Produced flue gas is cleaned and released to atmosphere. Final product of this type of facility is steam that can be used to produce energy. This type of configuration is categorized as a incineration plant with all the legal consequences.

Second group (B) of facilities includes gasification of wastes resulting in cleaned syngas, that can be used either to produce energy (in-situ or transported to another facility) or for further chemical processing, for instance production of methanol, synthetic fuels or ammonia. In this situation gasification with synthesis falls in a category of waste recycling which is in considered higher in a hierarchy of waste management. Still unclear question is to qualify distant gas combustion. In case of natural gas quality it may be considered as a regular combustion process without the restriction imposed on incineration.

(A)

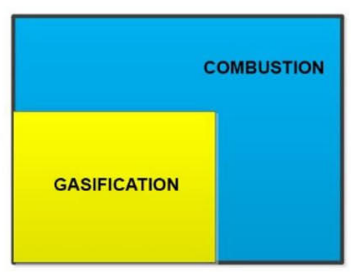

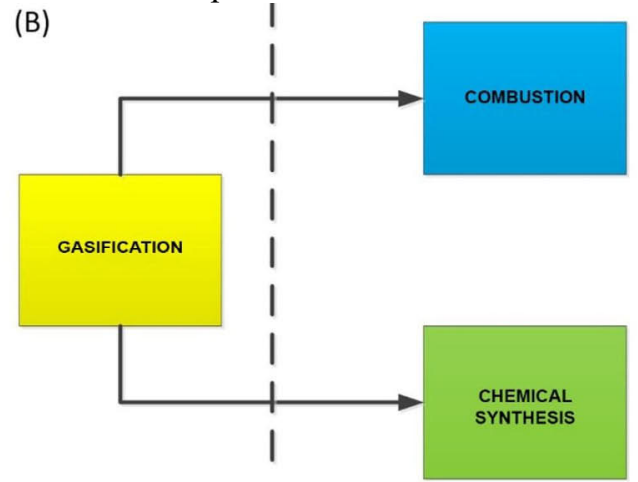

Fig. 3. Integration of technological units

One of the leading countries in the field of waste conversion is Japan, which from the beginning chose gasification as the main option suitable for waste conversion because it is able to provide satisfying performance in both, technological and environmental aspects. Two leading companies offering waste gasification systems in Japan are JFE Engineering Corporation [4], since 2003 having 10 fully operational plants in Japan and Nippon Steel \& Sumikin Engineering Co.[5], having 43 operating facilities working since 1980. The scale of both technologies is fully commercial and ranges from $10000-230000 \mathrm{Mg} / \mathrm{a}$.

Both Japanese technologies use similar types of moving bed reactor, requiring addition of extra coke to increase heating value of waste and also serving as grid to assure the flow of molten slag in a bottom part of the reactor. Also both of this technologies require air and enriched air for operation. Enriched air is used in bottom part of the gasifier to increase the temperature up to $1600^{\circ} \mathrm{C}$ to ensure ash melting [6].

The JFE High-Temperature Gasifying and Direct Melting Furnace is one of the most compact furnaces, which is able to gasify combustibles and melt ash in a single step. Combustibles of wastes are gasified by the high temperature of the furnace. Noncombustibles of wastes are melted and turned into slag and metals which can be reused. Since a reducing atmosphere is maintained in the interior of the furnace, hazardous heavy metals may vaporized to the gaseous phase and molten ash is converted to safe slag. The molten ash from the furnace bottom is quenched in a water-granulation conveyor to form granulated slag and metals [7].

Both of the aforementioned process are able to process wide range of wastes from municipal and commercial wastes, through ash and sewage sludge up to low calorific excavated landfill wastes and even toxic, hazardous and medical wastes. An important advantage is also a fact that they do not require any pretreatment and only limit is the size of ducts delivering feedstock to the reactor. 
Besides Japanese technologies also other corporations from different countries are interested in the field of waste converting, but they do not have many fully operational plants. The examples of such technologies are the ones offered by Alter NRG [8], Enerkem [9] and Leveraged Green Energy [10].

Alter NRG offers plasma gasifier with oxygen used as gasifying agent where various feedstocks can be gasified using the very high temperatures achievable with plasma. The gasifier is equipped with Westinghouse Plasma Corp. torch systems to ensure the internal temperatures in the reactor are sufficient to guarantee complete conversion of carbonaceous material to syngas and to melt all the inorganic material. Temperature inside the reactor reaches $1600^{\circ} \mathrm{C}$ near the plasma torch to ensure ash melting and the gas leaves this unit at temperature of about $850^{\circ} \mathrm{C}$.

Enerkem offers fluid bed gasification technology for pretreated municipal wastes.

LGE offers a process called Gasplasma, which is a two-step process in which organic waste is first gasified by heating it in a low oxygen environment. As a second step, the syngas is cleaned by a plasma torch, which cracks the complex organic compounds into their constituent parts resulting in a clean synthetic gas with even higher calorific content. It is believed that this technology is able to present efficiency of about $50 \%$ when producing heat (via combustion of syngas), but it was not tested in commercial application, because it has just one operating pilot plant located in the UK.

The summary of presented technologies is shown in Table 1.

Table 1 Summary of waste gasification technologies

\begin{tabular}{|c|c|c|c|c|c|}
\hline & JFE & Nippon & LGE & Enerkem & Alter NRG \\
\hline $\begin{array}{l}\text { Type of } \\
\text { gasifier }\end{array}$ & $\begin{array}{c}\text { moving } \\
\text { bed, coke } \\
\text { addition, } \\
\text { ash melting } \\
\text { unit }\end{array}$ & $\begin{array}{c}\text { moving } \\
\text { bed, coke } \\
\text { addition, } \\
\text { ash melting } \\
\text { unit }\end{array}$ & $\begin{array}{l}\text { Gasifier }+ \\
\text { plasma } \\
\text { converter } \\
\text { for syngas }\end{array}$ & $\begin{array}{l}\text { Fluid bed } \\
\text { gasification }\end{array}$ & $\begin{array}{c}\text { Moving bed, } \\
\text { plasma torch } \\
\text { for ash } \\
\text { melting }\end{array}$ \\
\hline Oxidant & $\begin{array}{l}\text { enriched } \\
\text { air, } \\
\text { air }\end{array}$ & $\begin{array}{c}\text { enriched } \\
\text { air, } \\
\text { air }\end{array}$ & oxygen & Air/oxygen & Air/oxygen \\
\hline $\begin{array}{c}\text { Feedstock } \\
\text { requirements }\end{array}$ & $\begin{array}{l}\text { none, can } \\
\text { gasify } \\
\text { medical } \\
\text { and } \\
\text { hazardous } \\
\text { wastes }\end{array}$ & $\begin{array}{l}\text { none, can } \\
\text { gasify } \\
\text { medical } \\
\text { and } \\
\text { hazardous } \\
\text { wastes }\end{array}$ & $\begin{array}{c}\text { Not } \\
\text { specified }\end{array}$ & $\begin{array}{l}\text { post-sorted } \\
\text { municipal } \\
\text { solid waste } \\
\text { (after } \\
\text { recycling } \\
\text { and } \\
\text { composting) }\end{array}$ & $\begin{array}{c}\text { sorted and } \\
\text { shredded (< } \\
15 \mathrm{~cm}), \text { can } \\
\text { gasify } \\
\text { medical and } \\
\text { hazardous } \\
\text { wastes }\end{array}$ \\
\hline Product & steam & steam & $\begin{array}{l}\text { syngas or } \\
\text { energy }\end{array}$ & $\begin{array}{l}\text { syngas for } \\
\text { chemical } \\
\text { production, }\end{array}$ & $\begin{array}{c}\text { clean } \\
\text { syngas, } \\
\text { production } \\
\text { of energy or } \\
\text { chemicals }\end{array}$ \\
\hline References & 10 & 43 & $\begin{array}{c}\text { None (1 } \\
\text { pilot plant) }\end{array}$ & $\begin{array}{c}1 \text { under } \\
\text { construction }\end{array}$ & $\begin{array}{l}6+2 \text { under } \\
\text { construction }\end{array}$ \\
\hline
\end{tabular}

\section{Model development}

Presented model is based on the Gibbs minimization method, which is well known and widely used to modeling complex processes such as gasification [11-14]. In this study 
gasification is modelled with modified Gibbs minimization method, which uses some experimentally obtained constraints to include the deviations from thermodynamic equilibrium state caused by kinetic influences on the process. Detailed description of the model, balance equations and equilibrium modifications, are presented in author's previous study [15]. The following assumptions were applied to perform following calculations:

- gasification reactor is assumed to be a moving bed reactor, fed from the top,

- waste feed is $1000 \mathrm{~kg} / \mathrm{h}$,

- the basic amount of air fed into the reactor is calculated based on equivalence ratio typical for biomass gasification $[16,17] \mathrm{ER}=0.25$,

- enriched air is assumed to contain up to $35 \%$ of oxygen,

- nitrogen from air and inorganic substance from is treated as inert and does not influence chemistry of the process,

- heat loss of the system is estimated to be equal to $15 \%$ of physical enthalpy of products.

The reactor itself can be divided into 3 zones: drying, gasification and ash melting. For this reason, aforementioned model was improved and two additional modules were included. First one is used to calculate energy consumption in drying process and the second one calculates energy consumption for ash melting.

Furthermore the calculations were performed in two different configurations presented in Figure 4. In first case, both wastes and additional coke were treated as one stream provided into the gasification reactor and they both undergo to all gasification reactions leading to a final product. Gibbs minimization is performed on a mixture of coke and waste and final gas composition is calculated. Drying of wastes results in decreasing temperature of produced syngas. It is assumed that biomass reaches temperature of $150^{\circ} \mathrm{C}$ in the drying zone and as a result syngas is cooled to the temperature $\mathrm{T}_{\text {out }}$ that can be calculated by solving the equation based on the energy balance (1) of this process.

$$
\Delta h_{\text {vap }}+m_{w} C_{p_{\text {waste }}}\left(T_{d}-T_{0}\right)+n_{\text {gas }} C_{p_{g}}\left(T_{\text {out }}-T_{0}\right)=n_{\text {gas }} C_{p_{g}}\left(T_{\text {proc }}-T_{0}\right)
$$
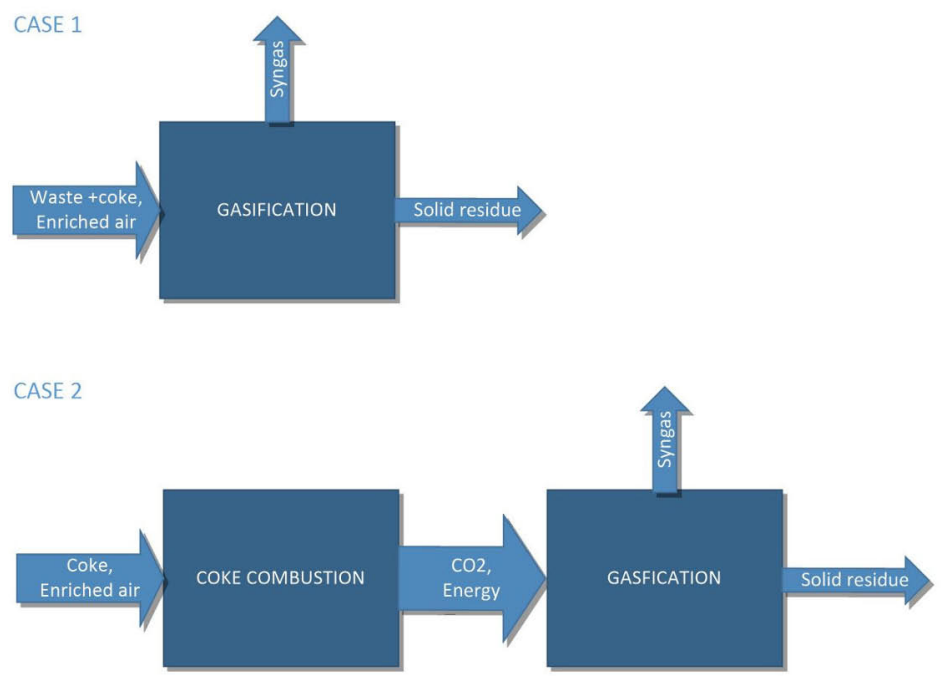

Fig. 4. Two cases of model configuration 
Energy consumption needed for ash melting is included in overall energy balance of gasification process as a part of heat loss. Overall energy balance is used to calculate temperature of gasification zone. Ash melting temperature was approximated using equations proposed by Holubcik et al. [18] It was assumed that ash consist only of 4 main components $\mathrm{SiO}_{2}, \mathrm{CaO}, \mathrm{Al}_{2} \mathrm{O}_{3}$ and $\mathrm{Fe}_{2} \mathrm{O}_{3}$.

In case 2 coke and enriched air are treated separately. Coke undergoes partial combustion and produced heat is used to melt ash and deliver energy to endothermic gasification reactions. In second step Gibbs minimization is performed on wastes with air as gasifying agent and energy released during combustion is added to the overall balance of the process. In this case the excess of energy produced in melting zone is added to energy balance of gasification zone and gasification temperature is calculated. Drying zone is calculated in the same manner as in Case 1.

Chemical composition of such wastes used for the calculations is presented in Table 2 while typical morphology of municipal wastes is presented in Table 3.

Table 2 Average waste composition (as received)

\begin{tabular}{|c|c|c|c|c|c|l|l|c|}
\hline & $\mathbf{C}$ & $\mathbf{H}$ & $\mathbf{N}$ & $\mathbf{S}$ & $\mathbf{O}$ & Moisture & Ash & Cl \\
\hline$\%$ mas & 50.50 & 3.00 & 1.90 & 0.46 & 21.10 & 21.54 & 0.30 & 1.20 \\
\hline
\end{tabular}

Table 3 Typical morphology of municipal waste

\begin{tabular}{|l|c|}
\hline \multicolumn{1}{|c|}{ Type } & {$[\%]$} \\
\hline organic wastes & 19.7 \\
\hline paper & 14.6 \\
\hline plastics & 14.1 \\
\hline particles $<10 \mathrm{~mm}$ & 9.6 \\
\hline glass & 8.6 \\
\hline particles $10-20 \mathrm{~mm}$ & 8.1 \\
\hline others & 5.9 \\
\hline food waste & 5.4 \\
\hline textiles & 3.9 \\
\hline Multicomponent waste & 3.6 \\
\hline neutral & 3.3 \\
\hline metals & 2.0 \\
\hline wood & 0.6 \\
\hline green wastes & 0.3 \\
\hline electrical wastes & 0.27 \\
\hline hazardous materials & 0.02 \\
\hline batteries & 0.01 \\
\hline Total & $\mathbf{1 0 0}$ \\
\hline
\end{tabular}

\section{Results and discussion}

Presented calculations were performed only for technologies including addition of coke (reference to Nippon and JFE). As was previously mentioned they both present similar 
constructions of gasifiers and both can be treated as moving bed reactors. Because of that and the lack of detailed diagram flows of both technologies it was decided that they can be modeled by the same algorithm. Technologies using plasma torch or plasma reactor were neglected in this part of the study. According to the aforementioned assumption for Case 1 air stream was set to be $2000 \mathrm{~m}^{3} / \mathrm{h}$. It remained constant and only oxygen concentration was change from ambient air up to $35 \%$ of oxygen to observe the changes in gas composition and process temperature. Syngas composition is presented in Fig. 5. As can be seen the increase in carbon monoxide and carbon dioxide concentration can be observed as well as in the amount of syngas that is produced (Fig. 8). Also with the increasing amount of oxygen an increase in gasification temperature is observed which grows from $1250 \mathrm{~K}$ form ambient air up to $1600 \mathrm{~K}$ for $35 \%$ oxygen. Gas temperature after drying of biomass remains constant at about $600 \mathrm{~K}$ and is does not depend on oxygen level. Heating value of produced syngas presents maximum for oxygen concentration at about 30\% (Fig. 7). Fig. 8 also presents carbon conversion changes. Optimal conversion level is reached for highest oxygen concentration and highest temperature.

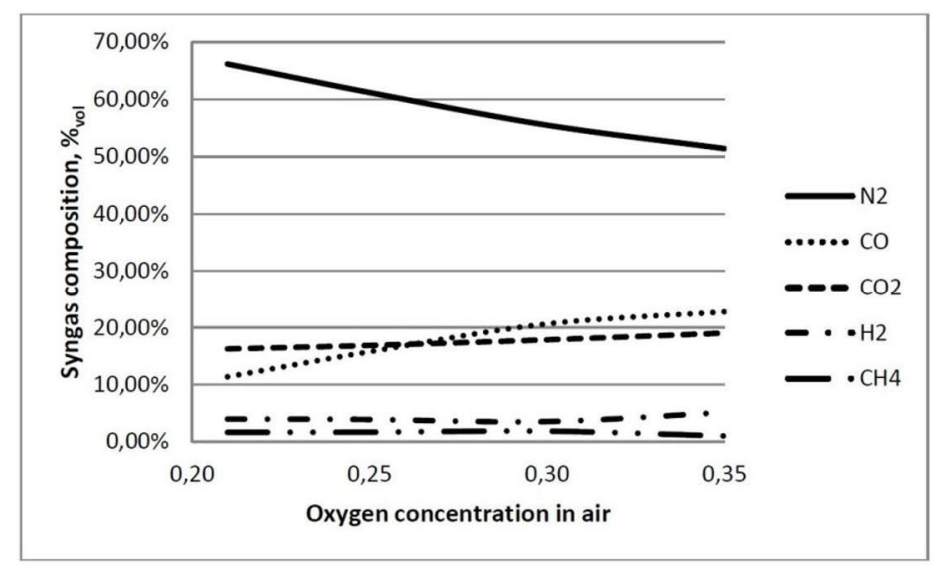

Fig. 5. Syngas composition as a function of oxygen concentration (case 1)

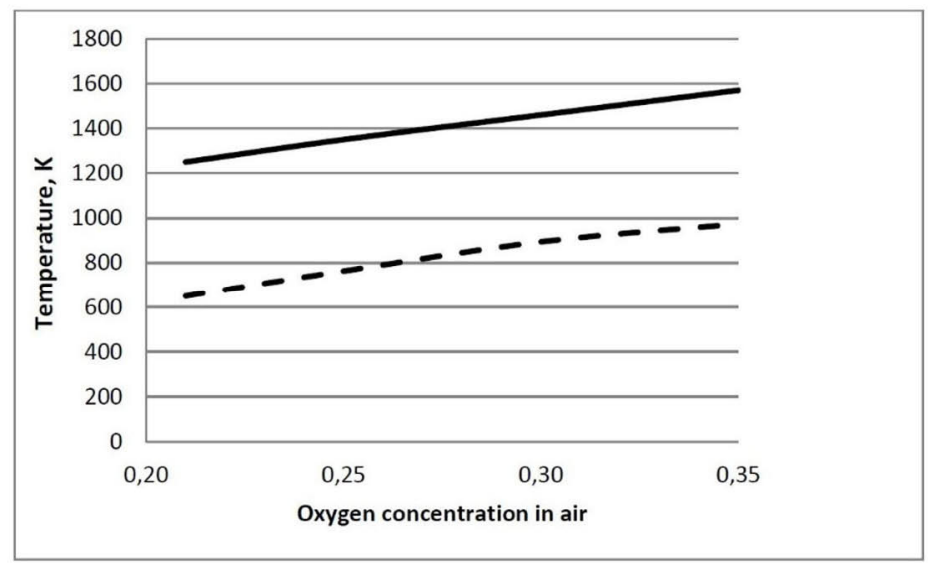

Fig. 6. Gasification and final gas temperatures as a function of oxygen concentration 


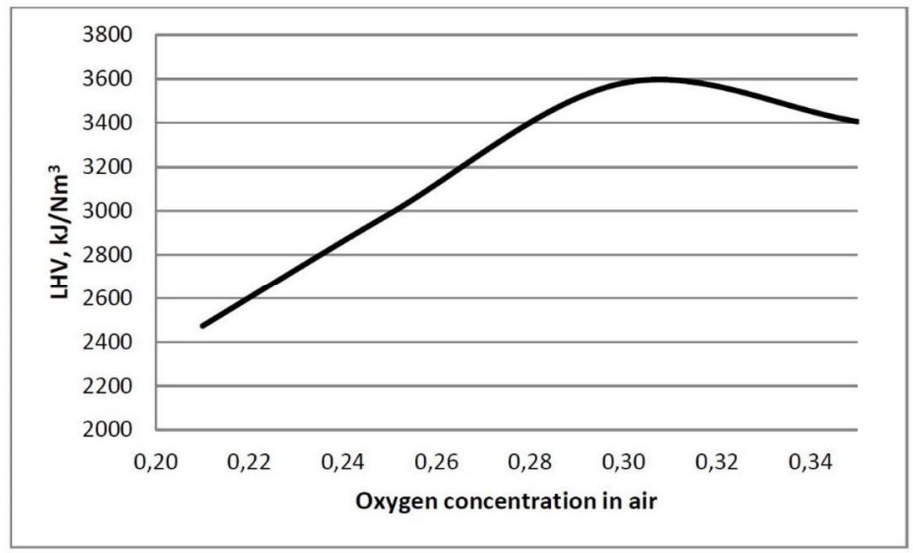

Fig. 7. Syngas LHV

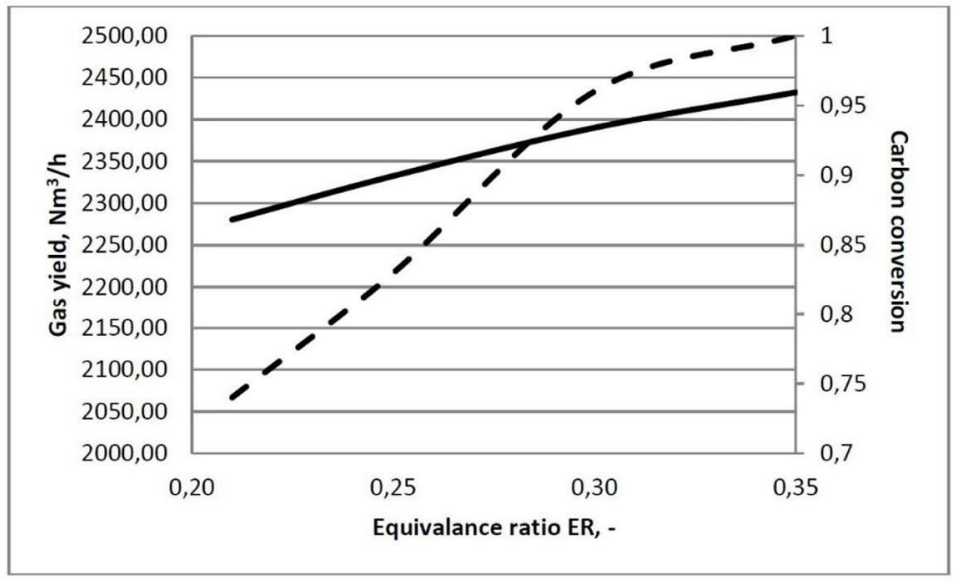

Fig. 8. Gas yield (solid) and carbon conversion efficiency (dotted)

For Case 2 additional coke was first partially burned in the atmosphere of enriched air and produced energy was partly used for ash melting and the excess of energy is added to energy balance of gasification block. Additionally carbon dioxide and nitrogen from coke combustion is added to gasification as an extra gasification agent. Basic gasification agent is air aid it's amount was calculated based on equivalence ratio which was changed from $\mathrm{ER}=0.2$ up to $\mathrm{ER}=0.35$. This resulted in different streams of gasification agent ranging between $1500-2600 \mathrm{Nm}^{3} / \mathrm{h}$. Fig. 9 presents changes in syngas composition with the change of ER ratio. A slight increase in the concentration of carbon dioxide is observed as well as an increase in the amount of carbon monoxide. Both hydrogen and methane concentrations are on low level and do not exceed 4\%. Fig. 10 shows significant increase in gas yield, but that is mainly caused by increasing stream of gasification agent and amount of oxygen that is fed to the system. Similarly to case one, carbon conversion reaches $100 \%$ for the highest stream of oxygen. Also with the increase of oxygen amount one can observe an increase in both gasification and final syngas temperature. Similarly to the previous case temperature drop is constant at about $600 \mathrm{~K}$. LHV of produced syngas (Fig. 11) also shows maximum value for ER equal to approximately 0.25 . 
Comparing both models two significant differences can be observed regarding nitrogen concentrations and concentrations of carbon monoxide and carbon dioxide. In case 1 higher concentrations of carbon monoxide and carbon dioxide were obtained. Predicted temperatures were similar in both cases as well as the values of LHV of produced syngas, which was slightly higher for case two.

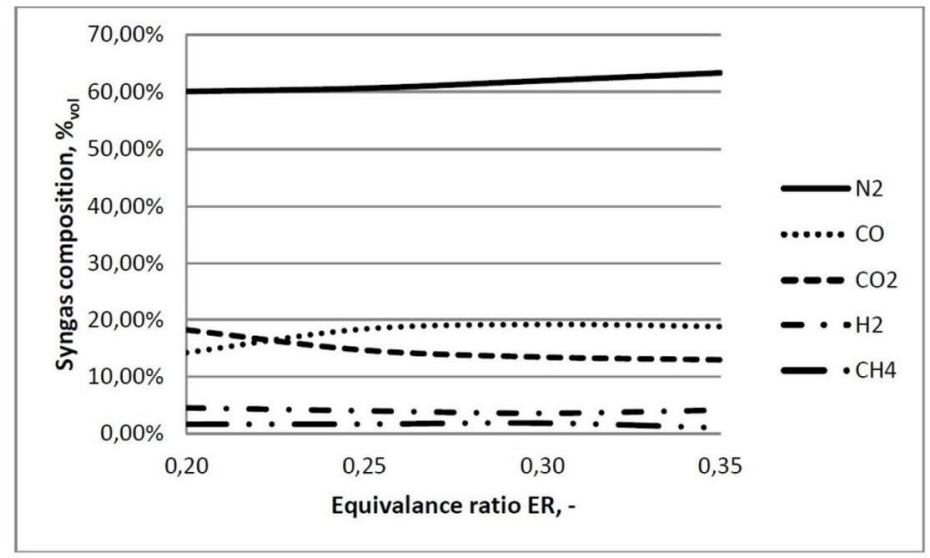

Fig. 9. Syngas composition as a function of oxygen concentration

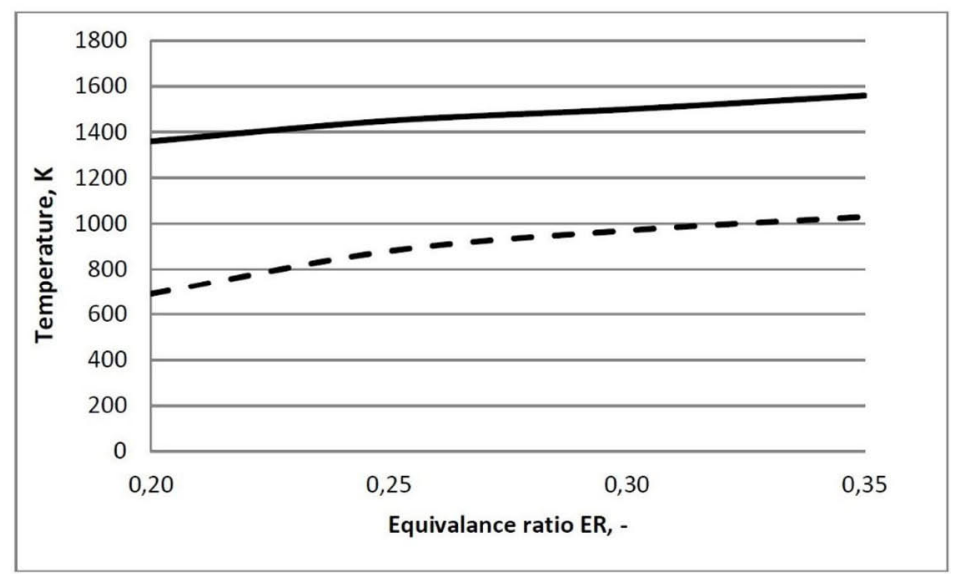

Fig. 10. Gasification and final gas temperatures as a function of oxygen concentration 


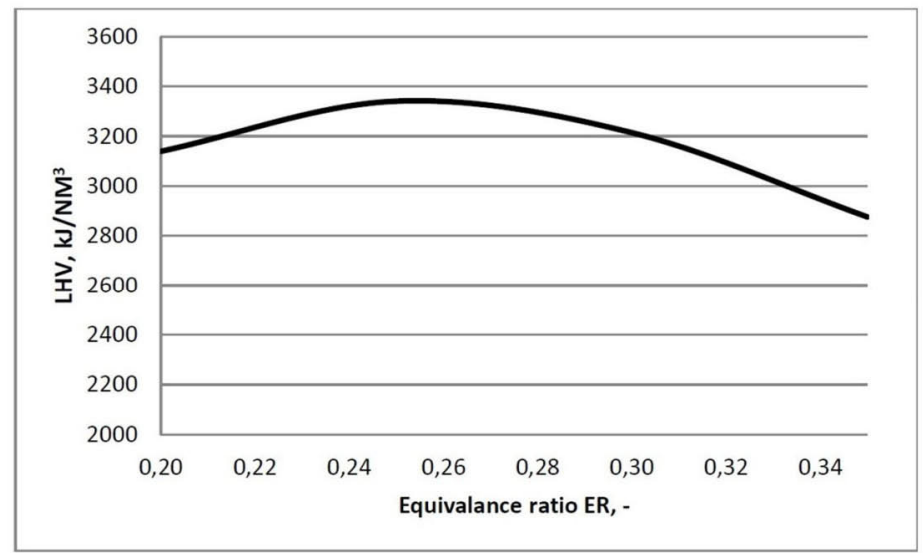

Fig. 11. Syngas LHV

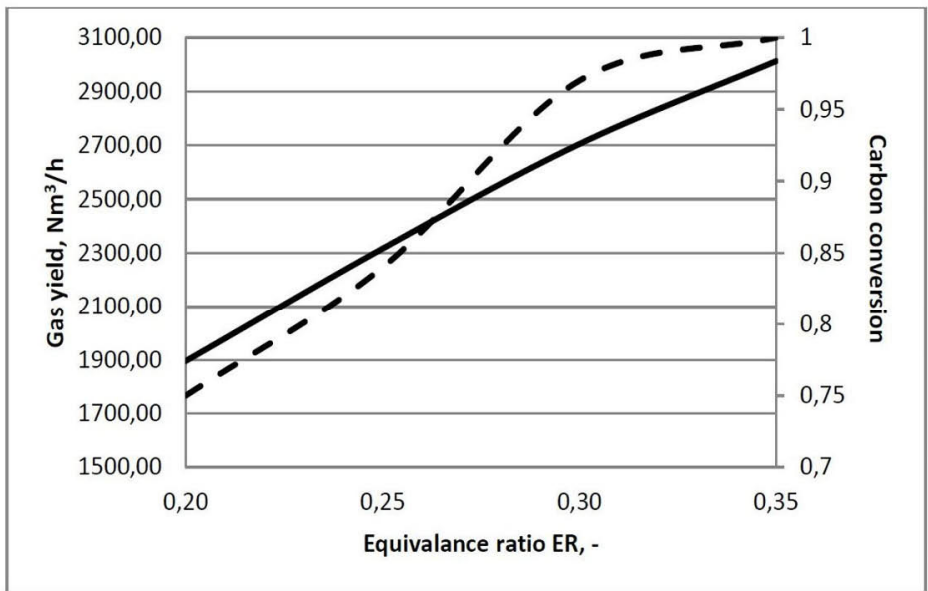

Fig. 12. Gas yield (solid) and carbon conversion efficiency (dotted)

\section{Conclusions}

An equilibrium model based on Gibbs minimization method was used to simulate the possible performance of two commercially available technologies in municipal waste gasification - JFE and Nippon Steel. Two different model cases with different approach to additional coke combustion, were presented, both producing similar results concerning final gas composition waste conversion and temperature.

- There is about $20 \%$ vol. of $\mathrm{CO}$ and $\mathrm{CO}_{2}$, while concentrations of $\mathrm{H}_{2}$ and $\mathrm{CH}_{4}$ are much lower and do not exceed $5 \%$ vol,

- The maximum LHV is reached for $25-30 \%$ of oxygen in gasifying agent. Produced gas LHV is approximately $3.5 \mathrm{MJ} / \mathrm{Nm}^{3}$

- $\quad$ Estimated gas yield ranges between $2.6-3 \mathrm{Nm}^{3} / \mathrm{kg}$ of waste. 
Due to lack of detailed data about presented technologies, proper validation of presented values is impossible. Presented model may be useful in future assessing the technologies for perspective design of gasification facility and choosing proper feedstock for its operation.

Research was done within the framework of statutory work 11.11.210.213.

\section{References}

1. U. Arena, Waste Management 32, 625-639 (2012)

2. C.S. Psomopoulos, C.S., Bourka, A., Themelis, N.J., 2009. Waste-to-energy: a review of the status and benefits in USA. Waste Management 29, 1718-1724.

3. S. Consonni, M. Giugliano, M. Grosso, Waste Management 25, 123-135 (2005)

4. http://www.jfe-eng.co.jp/en/ (accesed 31.08.2016)

5. https://www.eng.nssmc.com/english/ (accesed 31.08.2016)

6. N. Tanigaki, Proven Waste Gasification Technology for Circular Society - Key Technical Information for Deployment, World Waste to Energy City Summit London, 2015

7. JFE High-Temperature Gasifying and Direct Melting Furnace System - Operational Results of "Fukuyama Recycle Power", JFE Technical Report, March 2011

8. http://www.alternrg.com/waste to energy/energy-from-waste/ (accesed 31.08.2016)

9. http://enerkem.com/about-us/technology/ (accesed 31.08.2016)

10. http://lgefund.net/technologies/(accesed 31.08.2016)

11. X. Li, Fuel 80, 195-207 (2001)

12. S. Shabbar., I. Janajreh Energy Conv .and Manag. 65, 755-763 (2013)

13. E. Esmaili, N. Mahinpey, C. Jim Lim, Chem. Engi. Res. and Des. 91, 1361-1369 (2013)

14. P. Kangas, I. Hannula, P. Koukkari, M. Hupa, Fuel 129, 86-94 (2014)

15. M. Ściążko, L. Stępień, Chem. and Proc. Eng. 36, 73-87 (2015)

16. A. Bhavanam, R.C.Sastry, Int. jour. Of Chem. Eng. And App. 6, 425*-432 (2011)

17. B. Sharmina, Energies 6, 6508-6524 (2013)

18. M. Holubcik, J. Jandacka, M. Malcho, , The holistic approach to Env. 5, 119-125 (2015) 